MAREK SZAJT

Politechnika Częstochowska, Polska • Czestochowa University of Technology, Poland

\title{
Przestrzenno-czasowa analiza aktywności patentowej regionów Unii Europejskiej
}

\section{Spatio-temporal Analysis of Patent Activity for European Union Regions}

\begin{abstract}
Streszczenie: Artykuł dotyczy badania aktywności patentowej, będącej odzwierciedleniem aktywności innowacyjnej, na poziomie regionów. W badaniu wykorzystano dane pochodzące z Eurostatu, obejmujące regiony Unii Europejskiej w latach 1999-2012. Jako główne determinanty zmian poziomu aktywności patentowej wskazano zasoby ludzkie mierzone liczbą, personelu $B+R$, badaczy zatrudnionych w tym sektorze i zasobów ludzkich dla nauki i techniki, oraz czynnik finansowy w postaci nakładów brutto na działalność B+R. Cele badania to identyfikacja poziomów aktywności patentowej oraz określenie potencjału innowacyjnego na poziomie regionalnym. W pracy wykorzystano model przestrzenno-czasowy z efektami stałymi i konstrukcją korekty błędem. Zastosowane podejście umożliwia z jednej strony przedstawienie prawidłowości w ujęciu zagregowanym, z drugiej zaś - różnicowanie wyników w zależności od przyporządkowania przestrzennego. Ponadto konstrukcja błędem wskazuje na krótko- i długoterminowe relacje oraz zbieżność - lub jej brak w odniesieniu do pewnego hipotetycznego punktu równowagi. Otrzymane wyniki wskazują na podstawowe różnice oraz określają ich wielkość pomiędzy badanym zjawiskiem w regionach i ukierunkowują dalsze badania innowacyjności regionów. Wyniki te nie tylko potwierdzają założenia o silnym zróżnicowaniu aktywności patentowej jako cechy własnej regionu, ale też pokazują rozbieżności w oddziaływaniu tych samych czynników (przy różnych uwarunkowaniach) na badaną aktywność w krótkim i długim okresie.
\end{abstract}

Abstract: The article is concerned with the research of patent activity reflecting the innovativeness activity at regional level. The study used data from Eurostat covering the regions of the European Union and the years 1999-2012. As the main determinants of changes in the level of patent activity identified were the following: human resources as measured by R\&D personnel; researchers employed in this sector and human resources in science and technology; and the financial factor in the form of gross expenditure on R\&D. The aim of the study was to identify the level of patent activity and to identify innovation potential at regional level. The study used a spatio-temporal model with fixed effects and error correction mechanism. The approach allows to indicate the regularities in aggregate terms on the one hand, and the differentiation of results depending on the assignment planning on the other. Moreover, the design error indicates a short-term and long-term relationships and convergence - or lack thereof - in relation to a hypothetical equilibrium point. The results indicate and determine the size of key differences between patent activity in the studied regions, as well as provide direction for further research of innovation of regions. The results confirmed not only the foundation of a strong differentiation of patent activity as a feature in their own region but also pointed out the similarities in the effects of these same factors (in different conditions) on the patent activity in the short and long term. 
Słowa kluczowe: aktywność patentowa; działalność B+R; model przestrzenno-czasowy; potencjał innowacyjny; regiony

Keywords: activity of R\&D; innovation potential; patent activity; regions; spatio-temporal model

Otrzymano: 27 grudnia 2015

Received: 27 December 2015

Zaakceptowano: 10 lipca 2016

Accepted: 10 July 2016

Sugerowana cytacja / Suggested citation:

Szajt, M. (2016). Przestrzenno-czasowa analiza aktywności patentowej regionów Unii Europejskiej. Prace Komisji Geografii Przemysłu Polskiego Towarzystwa Geograficznego, 30(3), 91-104.

\section{WSTĘP}

We współczesnych badaniach ekonomicznych jako jedno ze źródeł pożądanego wzrostu gospodarczego wskazuje się politykę innowacyjną czy też innowacyjność jako taką. Mimo zauważalnych powiązań pojawia się tu jednak problem identyfikacji i pomiaru aktywności innowacyjnej praktycznie na wszystkich obserwowanych poziomach. Jednym z jej przejawów jest aktywność patentowa (Acsa, Anselin, Varga, 2002). Do niedawna brano pod uwagę tę aktywność jedynie w ujęciu terytorialnym państwa. Wraz z rozwojem ekonomii i towarzyszącym temu zjawisku rozwojem analiz, także mikroekonomicznych czy mezoekonomicznych, zaczęto rozpatrywać niektóre z kategorii ekonomicznych na poziomie przedsiębiorstwa, a także regionu. W tym ujęciu aktywność patentowa na poziomie regionalnym może być traktowana jako pewna miara aktywności innowacyjnej.

Celem niniejszego artykułu jest identyfikacja poziomów aktywności patentowej oraz określenie potencjału innowacyjnego na poziomie regionalnym w państwach Unii Europejskiej. Potencjał ten jest możliwy do wyznaczenia z wykorzystaniem narzędzi ekonometrycznych i wpływa jako stymulator (lub hamulec) na podstawowe determinanty aktywności patentowej. $\mathrm{W}$ badaniach korzystano z danych Eurostatu na temat regionów klasyfikacji NUTS 2 (270 regionów) - 28 państw z lat 1999-2012. Jako miarę aktywności patentowej przyjęto liczbę zgłoszonych przez rezydentów patentów, co jest jednym z ujęć spotykanych w literaturze (Firlej, 2013; Tavassoli, Carbonara, 2014; Yanhui, Huiying, Jing, 2015). Niektórzy badacze jako miarę aktywności wykorzystują liczbę przyznanych patentów (Corredoira, Banerjee, 2015), lecz ze względów administracyjnych i nie tylko (Szajt, 2010) miara ta wydaje się być nieco mniej odpowiednia.

Działalność innowacyjna warunkowana jest różnymi czynnikami, które możemy określić jako jej podstawowe determinanty. Powstaniu innowacji bezsprzecznie towarzyszyć musi inwencja lub przypadek. W obecnej rzeczywistości gospodarczej jest to jednak niewystarczające. Jeśli w definicji innowacji przyjmiemy, że „proces innowacyjny w znaczeniu czynnościowym zamyka się w przedziale od pierwszej koncepcji do pierwszej realizacji" (Janasz, 1999: 71), to jej niezbędnymi czynnikami są: środki finansowe potrzebne do realizacji poszczególnych etapów jej powstawania oraz czynnik ludzki - pomysłodawca, twórca, wykonawca, realizator. W ujęciu zewnętrznym 
zaistnieć muszą również odpowiednie przesłanki, by innowacja została zauważona, wykorzystana, by odniosła sukces, zwłaszcza w ujęciu komercyjnym - ekonomicznym. Do tego niezbędny jest odpowiedni poziom zamożności w obszarze traktowanym jako rynek zbytu oraz odpowiednie kwalifikacje odbiorców, umożliwiające wykorzystanie zalet płynących z powstałej innowacji oraz odpowiedni klimat społeczny (Zioło, 2012: 24; Yoon, Yun, Lee, Philips, 2015).

Pomiar tych poszczególnych czynników jest możliwy i dużo łatwiejszy niż pomiar innowacyjności samej w sobie. Zasoby ludzkie mierzy się zwykle według liczby personelu, również w zawężeniu do badaczy i techników zatrudnionych w sektorze badawczo-rozwojowym $(\mathrm{B}+\mathrm{R})$. Od pewnego czasu posługujemy się też kategorią zasoby ludzkie dla nauki i techniki (human resources for sciences and technologies, HRST), do której zalicza się osoby z wykształceniem trzeciego stopnia, osoby mające zawody wymagające wyższego wykształcenia oraz pracowników, którzy ukończyli studia wyższe w zakresie nauk ścisłych i technicznych i pracują w sferze nauka i technika (Markowska, 2012). Z kolei nakłady - ze względu na trudno dostępne dane dotyczące innowacji samych w sobie (być może z powodów definicyjnych lub braków w ewidencji na poziomie przedsiębiorstw) - definiowane są zwykle jako wydatki brutto na działalność badawczo-rozwojową $(\mathrm{B}+\mathrm{R})$ w podziale na sektory finansowania i wykorzystania.

Warunki zewnętrzne określane są zazwyczaj z wykorzystaniem poziomu PKB jako miary rozwoju gospodarczego. W niniejszym ujęciu miary te odniesione zostaną do regionów Unii Europejskiej. Dostępność danych jest obecnie dość duża, jednak w niektórych przypadkach pojawiają się braki, dwuletnia częstotliwość gromadzenia czy niemożność oszacowania, wynikająca ze zmian w ujęciu administracyjnym, niekoniecznie możliwych do przeszacowania do warunków poprzednich lub nowych.

\section{SYTUACJA SEKTORA B+R W REGIONACH EUROPEJSKICH}

Sytuacja sektora B+R w Unii Europejskiej jest daleka od jednorodnej (Proniewski, 2013). Różnice dotyczą nie tylko państw (co jest przedmiotem wielu analiz), ale również - a być może przede wszystkim - regionów (Strahl, 2012; Krawczyk-Sokołowska, 2012; Brezdeń, Spallek, 2013). Odmienny jest nie tylko sposób funkcjonowania w Europie systemów innowacyjnych, zróżnicowane są też: poziom rozwoju, system nauki, sposób inwestowania w działalność innowacyjną i badawczo-rozwojową.

Dane prezentowane na ryc. 1. wskazują wyraźnie na zróżnicowanie poziomu finansowania działalności $\mathrm{B}+\mathrm{R}$ nie tylko między państwami, ale również między regionami należącymi do tego samego państwa. Różnice te są znaczne i wynoszą od kilku do kilkudziesięciu procent. Najbogatszy region niemiecki - Stuttgart - wydaje na działalność B+R 6,19\% PKB, podczas gdy region Koblenz - zaledwie 0,67\% PKB. Podobną różnicę dostrzegamy we Francji, gdzie w regionie Midi-Pyrénées rejestrujemy wydatki na poziomie 4,84\% PKB, a na Korsyce (Corse) - 0,36\% PKB.

Odniesienie tych wielkości do PKB może być jednak złudne. Wydaje się, że nie gorszym porównaniem będzie zestawienie nakładów na działalność $\mathrm{B}+\mathrm{R}$ w odniesieniu do bezpośrednich partycypantów, czyli personelu $B+R$ w tych regionach. $W$ tym ujęciu 
Ryc. 1. Wydatki brutto na działalność B+R jako \% PKB w regionach Unii Europejskiej w roku 2014 (lub w ostatnim, dla którego dostępne są dane)

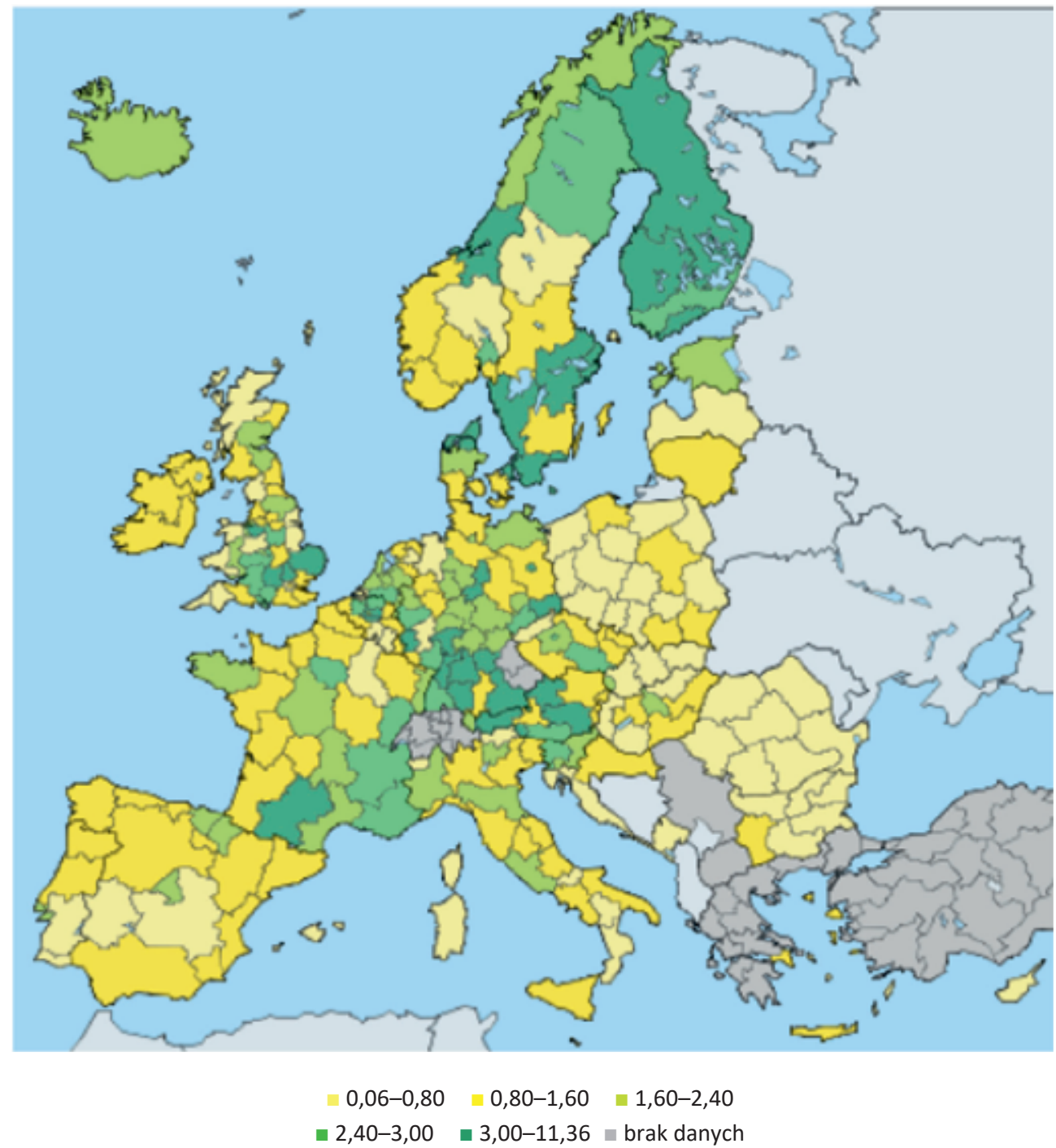

Źródło: Eurostat (2015)

zróżnicowanie dla państw wyróżniających na swym terytorium co najmniej dwa regiony wygląda jak na ryc. 2 .

Postrzeganie nakładów na działalność $\mathrm{B}+\mathrm{R}$ w odniesieniu do personelu realizującego działania innowacyjne zmienia się diametralnie. Okazuje się, że najwyższym poziomem finansowania (średnio) w Unii Europejskiej charakteryzują się Niemcy, Austria i Szwecja, przy czym regionem o najwyższym dofinansowaniu personelu $B+R$ jest brytyjski Cheshire, a najsłabszym - bułgarski Severen Tsentralen. Trzeba jednak 
Ryc. 2. Rozrzut wydatków na działalność B+R (GERD) w odniesieniu do personelu zatrudnionego $\mathrm{w}$ sektorze $\mathrm{B}+\mathrm{R}$ w regionach wybranych państw europejskich

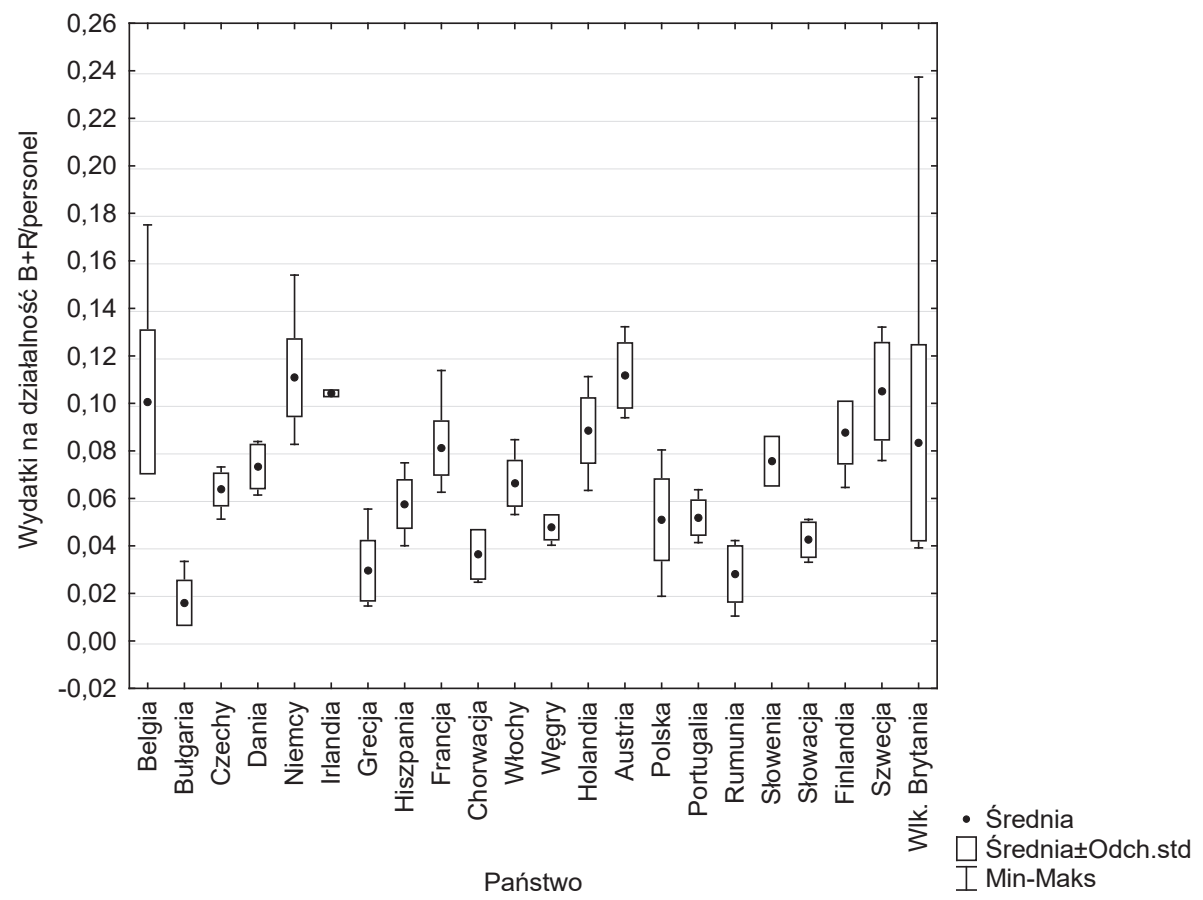

Źródło: opracowanie własne na podstawie danych Eurostatu (2015)

zauważyć, że jeśli chodzi o finansowanie, to w tym ujęciu również występują diametralne różnice - przykładowo najsłabszy finansowo region Wielkiej Brytanii Eastern Scotland wydaje niespełna 17\% nakładów najzamożniejszego regionu. Nawet w słabej finansowo (w odniesieniu do innych państw) Polsce region, który według tych zestawień przeznacza na ten cel najwięcej funduszy, wydaje czterokrotnie więcej niż region najuboższy.

Nie tylko poziom finansowania działalności B+R jest zróżnicowany, ale również jego wykorzystanie. Praktycznie każdy z regionów charakteryzuje się wysokim poziomem koncentracji środków wydawanych na badania i rozwój w jednym z sektorów. Sektor przedsiębiorstw generuje powyżej 50\% nakładów na B+R w 142 regionach, a w 44 - powyżej 75\%, najwięcej w regionie Herefordshire, Worcestershire i Warwickshire (Wielka Brytania) - 99,6\%, a najmniej na Wyspach Jońskich (Ionia Nisia, Grecja) - 1,1\%. Sektor publiczny (rządowy) generuje powyżej 50\% środków w pięciu regionach, powyżej 1/3 w 23, najwięcej w regionie Bukareszt-Ilfov (Bucuresti-Ilfov, Rumunia) - 66,9\%, a najmniej w Tees Valley i Durham (Wielka Brytania) - 0,05\%. Sektor szkół wyższych największą rolę w finansowaniu odgrywa w 43 regionach, powyżej 1/3 nakładów gromadzi w 98 regionach, największym udziałem szczyci się tu Kalabria (Włochy) 84,2\%, a najmniejszym Cheshire (Wielka Brytania) - 0,05\%. 
Ryc. 3. Średnia liczba badaczy w przeliczeniu na osoby aktywne zawodowo w regionach Unii Europejskiej w roku 2012 (lub ostatnim możliwym) oraz jej maksymalne i minimalne wartości

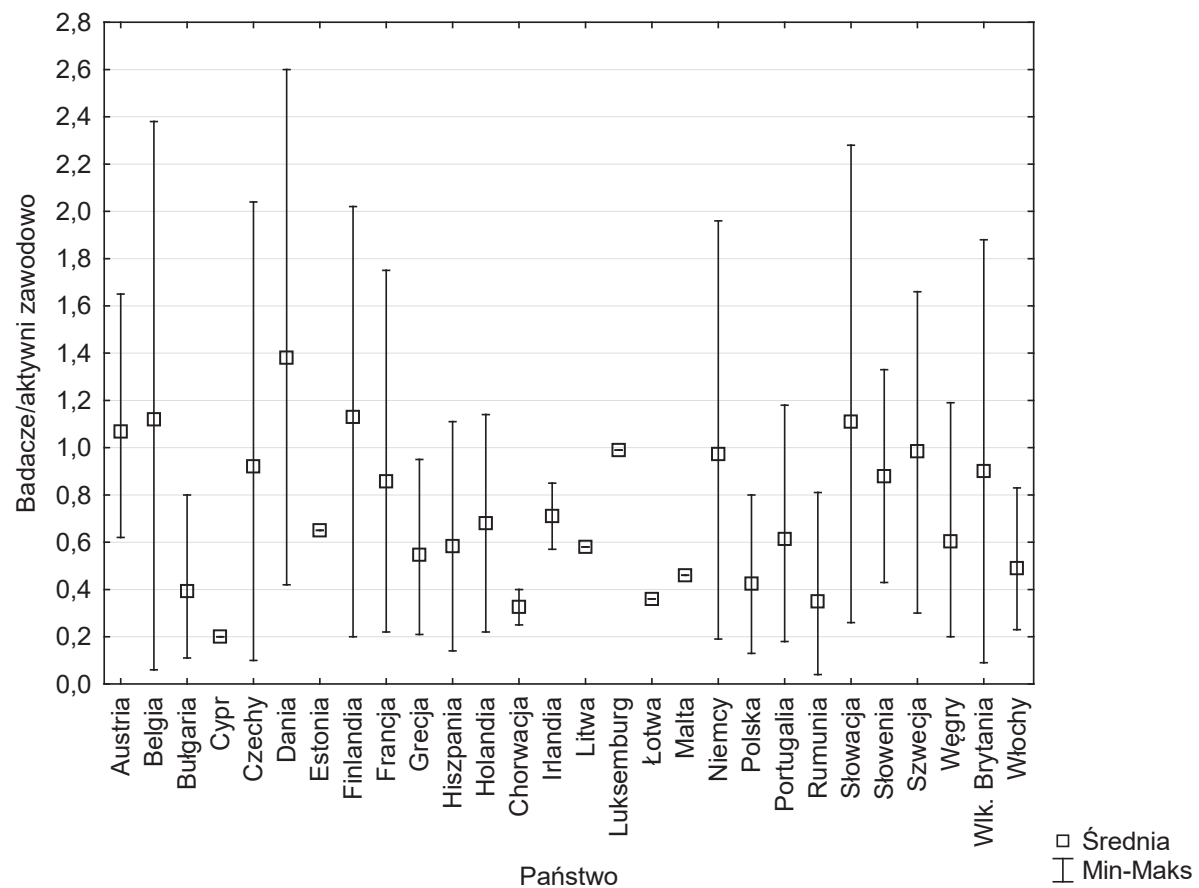

Źródło: opracowanie własne na podstawie danych Eurostatu (2015)

Co warte zauważenia, regiony uważane za najbardziej rozwinięte, również pod względem innowacyjności, to te, których finansowanie pochodzi w znacznej mierze ze strony przemysłu. Wydaje się, że generowanie innowacji przez sektor przedsiębiorstw wzmacnia możliwość ich późniejszego rzeczywistego wykorzystania i - co za tym idzie - zwrotu poniesionych nakładów, chociaż można spotkać się również z analizami prowadzącymi do innych wniosków (Quatrado, 2009).

Kolejnym czynnikiem, niezwykle istotnym w kształtowaniu innowacyjności na każdym jej poziomie, jest kapitał ludzki. Trzeba tu zauważyć, że podstawowym nośnikiem innowacyjności w sektorze $B+R$ są przede wszystkim badacze. To ich inwencja, realizowana niekiedy przez pozostały personel, stanowi o potencjale innowacyjnym. Zasoby te przedstawiamy zwykle w odniesieniu do liczby osób aktywnych zawodowo i - dla pełniejszej porównywalności - w przeliczeniu na pełne etaty. Jest to uzasadnione również ze względu na ewentualną interpretację otrzymanych wyników, w których niepełne wartości nie stanowią problemu w odniesieniu nie do osób, a do czasu ich pracy.

Dane przedstawione na ryc. 3 wskazują wyraźnie na silną dyspersję w zakresie zatrudnienia w sektorze $\mathrm{B}+\mathrm{R}$ na poziomie państw (i Unii jako całości). Wskaźnik zatrudnienia w Danii sięga od 0,42\% dla regionu Sjælland do 2,60\% dla Hovedstaden. Jest to jednocześnie najwyższy wskaźnik wobec najniższego dla rumuńskiego Regionu Południowo-Wschodniego (Sud-Est) - 0,04\%. Współczynniki te są niemal dla wszystkich 
regionów państw nowej trzynastki mniejsze niż średnio dla państw skandynawskich (wyjątek stanowią słowacki Bratislavský kraj i słoweńska Zahodna Slovenija).

\section{ZRÓŻNICOWANIE AKTYWNOŚCI PATENTOWEJ W ŚWIETLE DANYCH STATYSTYCZNYCH}

Jeżeli chodzi o aktywność patentową w państwach Unii Europejskiej (ryc. 4.), jest ona skrajnie zróżnicowana.

Ryc. 4. Aktywność patentowa najsłabszych i najmocniejszych regionów oraz średnia dla państwa w roku 2011

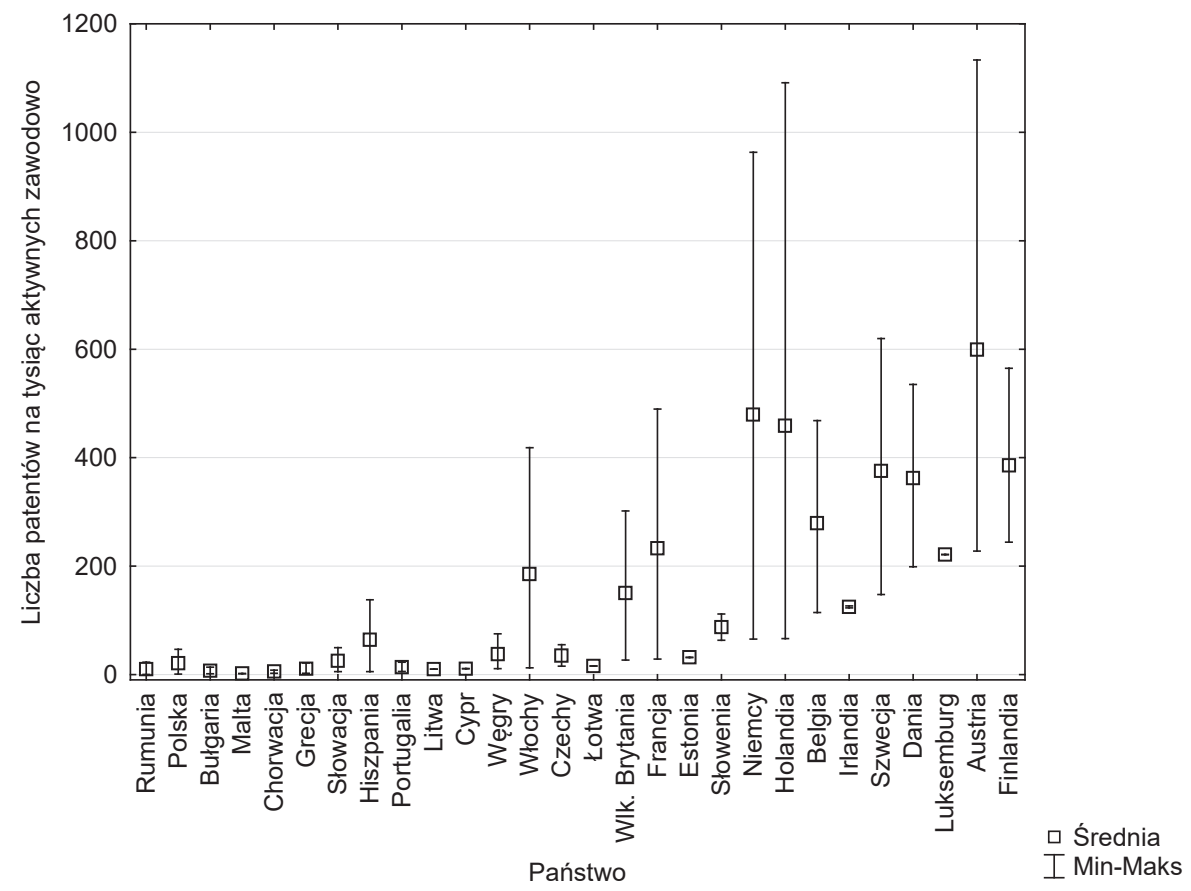

Źródło: opracowanie własne na podstawie danych Eurostatu (2015)

Poziom liczby patentów na tysiąc osób aktywnych zawodowo waha się od niemal zera do ponad tysiąca. Rozpiętość ta występuje nie tylko na przestrzeni Unii, ale również wielu państw, takich jak Niemcy, Holandia czy Austria. Poziom najsłabszego regionu Austrii jest i tak wielokrotnie wyższy niż regionów we wszystkich państwach przyjętych w ostatnich 10 latach do Unii, a także wyższy niż w Grecji, Hiszpanii, Portugalii i Irlandii. Jedynie 11 państw Unii charakteryzuje się wskaźnikiem na poziomie momentami - lub częściej - przekraczającym 200 patentów na 1000 osób aktywnych zawodowo. 
W niniejszym ujęciu wykorzystano percentyle (przesunięcie kategorii o 5 percentyli) do wskazania najlepszej i najsłabszej grupy regionów. Jeżeli chodzi o regiony, które najsłabiej wypadły w ujęciu aktywności patentowej jako pewnego miernika innowacyjności, w roku 2000 w grupie tej znajdowało się aż pięć regionów z Polski, poza tym osiem rumuńskich i jeden - Alentejo - z Portugalii. Jedynie jeden region rumuński - stołeczny - nie znajdował się na dole rankingu.

Tab. 1. Regiony, których aktywność patentowa mieściła się w ostatnich 5 percentylach w Unii Europejskiej w 2000 i 2011 roku

\begin{tabular}{|c|c|c|c|}
\hline \multicolumn{2}{|l|}{2000} & \multicolumn{2}{|l|}{2011} \\
\hline Region (państwo) & Wskaźnik & Region (państwo) & Wskaźnik \\
\hline $\begin{array}{l}\text { Region Południowy (Sud-Muntenia) } \\
\text { (Rumunia) }\end{array}$ & 0,089 & $\begin{array}{l}\text { Region Południowo-Zachodni (Sud- } \\
\text {-Vest Oltenia) (Rumunia) }\end{array}$ & 0,227 \\
\hline $\begin{array}{l}\text { Region Południowo-Wschodni (Sud-Est) } \\
\text { (Rumunia) }\end{array}$ & 0,099 & $\begin{array}{l}\text { Region Południowo-Wschodni (Sud- } \\
\text {-Est) (Rumunia) }\end{array}$ & 0,813 \\
\hline Region Centralny (Centru) (Rumunia) & 0,108 & Opolskie (Polska) & 0,833 \\
\hline Region Centralny (Centru) (Rumunia) & 0,108 & $\begin{array}{l}\text { Region Południowy (Sud-Muntenia) } \\
\text { (Rumunia) }\end{array}$ & 1,146 \\
\hline Warminsko-mazurskie (Polska) & 0,205 & Yugoiztochen (Bułgaria) & 1,374 \\
\hline $\begin{array}{l}\text { Region Północno-Wschodni (Nord-Est) } \\
\text { (Rumunia) }\end{array}$ & 0,336 & $\begin{array}{l}\text { Region Północno-Wschodni (Nord-Est) } \\
\text { (Rumunia) }\end{array}$ & 1,500 \\
\hline Zachodniopomorskie (Polska) & 0,342 & Malta & 1,855 \\
\hline Lubelskie (Polska) & 0,433 & Jadranska Hrvatska (Chorwacja) & 2,221 \\
\hline Kujawsko-pomorskie (Polska) & 0,664 & Yuzhen Tsentralen (Bułgaria) & 2,578 \\
\hline Lubuskie (Polskie) & 0,723 & Severozapaden (Bułgaria) & 2,585 \\
\hline $\begin{array}{l}\text { Region Południowo-Zachodni (Sud-Vest } \\
\text { Oltenia) (Rumunia) }\end{array}$ & 0,840 & Region Centralny (Centru) (Rumunia) & 2,656 \\
\hline $\begin{array}{l}\text { Region Północno-Zachodni (Nord-Vest) } \\
\text { (Rumunia) }\end{array}$ & 0,914 & Tesalia (Thessalia ) (Grecja) & 3,096 \\
\hline Alentejo (Portugalia) & 0,949 & Peloponez (Peloponnisos) (Grecja) & 4,029 \\
\hline Region Zachodni (Vest) (Rumunia) & 1,014 & $\begin{array}{l}\text { Macedonia Wschodnia i Tracja } \\
\text { (Anatoliki Makedonia, Thraki) Grecja) }\end{array}$ & 4,113 \\
\hline
\end{tabular}

Źródło: opracowanie własne na podstawie danych Eurostatu (2015)

Sytuacja po 10 latach zmieniła się wyraźnie. Przede wszystkim obecnie w tym zestawieniu znajduje się tylko jedno województwo z Polski - opolskie. Nadal jest w tej grupie pięć regionów rumuńskich, ale poza tym jest jeszcze jeden chorwacki, Malta i po trzy z Grecji i Bułgarii. Co bardzo ważne i warte zauważenia, poziom ostatniego decyla wynosił w 2011 roku 4,135, czyli czterokrotnie więcej niż w 2000 roku. Wyraźnie mniejsze zmiany dotyczą miejsc w czołówce.

Jeżeli chodzi o pierwszą czternastkę rankingu, jedynie belgijska Brabancja Walońska (Brabant Wallon), będąca w tym przedziale w 2000 roku, ustąpiła miejsca szwedzkiemu Sydsverige. Poza tym miejsce w tym zestawieniu mają stale zapewnione - po jednym regionie z Holandii, Austrii, Szwecji i Finlandii oraz dziewięć regionów 
niemieckich. Przewaga Niemiec w tym rankingu jest zdecydowana. Inną kwestią jest fakt wyrównywania się poziomu aktywności - być może pewnej konwergencji.

Tab. 2. Regiony, których aktywność patentowa mieści się w pierwszych 5 percentylach w Unii Europejskiej w 2000 i 2011 roku

\begin{tabular}{|l|r|r|}
\hline \multirow{2}{*}{ Region (państwo) } & \multicolumn{2}{c|}{ Wskaźnik w roku } \\
\cline { 2 - 3 } & \multicolumn{1}{c|}{2000} & \multicolumn{1}{c|}{2011} \\
\hline Vorarlberg (Austria) & 885,65 & 1133,35 \\
\hline Brabancja Północna (Noord-Brabant) (Holandia) & 1522,03 & 1091,33 \\
\hline Środkowa Frankonia (Mittelfranken) (Niemcy) & 938,27 & 963,17 \\
\hline Stuttgart (Niemcy) & 1331,31 & 957,09 \\
\hline Górna Bawaria (Oberbayern) (Niemcy) & 1306,18 & 856,05 \\
\hline Karlsruhe (Niemcy) & 865,39 & 793,06 \\
\hline Tybinga (Tübingen) (Niemcy) & 820,02 & 767,80 \\
\hline Górny Palatynat (Oberpfalz) (Niemcy) & 735,99 & 748,83 \\
\hline Fryburg (Freiburg) Niemcy) & 835,70 & 640,05 \\
\hline Sydsverige (Szwecja)* & 693,16 & 619,81 \\
\hline Sztokholm (Szwecja) & 745,66 & 597,72 \\
\hline Rheinhessen-Pfalz (Niemcy) & 938,33 & 578,78 \\
\hline Helsinki-Uusimaa (Finlandia) & 795,28 & 564,95 \\
\hline Darmstadt (Niemcy) & 887,13 & 556,80 \\
\hline Brabancja Walońska (Prov. Brabant Wallon) (Belgia)* & 852,29 & 468,38 \\
\hline
\end{tabular}

* Regiony, które występowały jedynie raz w pierwszym decylu.

Źródło: opracowanie własne na podstawie danych Eurostatu (2015)

Możliwe jest, że regiony (a właściwie podmioty tam funkcjonujące) o najwyższych współczynnikach aktywności, ze względu na niezmiernie ważny czas realizacji przedsięwzięcia (Kozioł-Nadolna, 2015), również ten niezbędny do patentowania, będący ograniczeniem z punktu widzenia wprowadzania nowoczesnej produkcji, patentują jedynie to, co uznają za niezbędne. Z kolei regiony słabsze, w obawie przed konkurencją, patentują wszystko, co tylko są w stanie uznać za wartościowe. Poziom zróżnicowania badanych wskaźników aktywności patentowej w tych latach wyraźnie się zmniejszył $(\mathrm{F}=1,549 ; \mathrm{p}=0,0002)$. Co gorsza, poziom innowacyjności również uległ spadkowi ze średniego 247,311 patentów na 1000 aktywnych zawodowo w roku 2000 do 198,719 $\mathrm{w}$ roku $2011 \mathrm{i}$ jest to spadek istotny statystycznie $(\mathrm{T}=1,7555 ; \mathrm{p}=0,0396)$.

\section{ZAŁOŻENIA MODELOWANIA AKTYWNOŚCI PATENTOWEJ NA POZIOMIE REGIONALNYM}

W dalszej części pracy przyjęto, że z wykorzystaniem modelu przestrzenno-czasowego uzyska się wyniki obrazujące zarówno różnice i podobieństwa pomiędzy 
regionalną aktywnością patentową, jak też siłę oddziaływania głównych determinant tej aktywności. W pracy abstrahuje się od współpracy międzyregionalnej, której siła oddziaływania jest coraz silniejsza (Wanzenböck, Scherngell, Brenner, 2014). Założono więc wstępnie, że:

- próba ma charakter przekrojowo-czasowy, dane dotyczą okresów z lat 1999-2012 i regionów NUTS dwóch państw europejskich należących do Unii Europejskiej,

- dopuszcza się możliwość interpolacji w przypadku pojawienia się incydentalnych braków danych lub rzadszej niż roczna powtarzalności gromadzonych wyników,

- aktywność patentowa jest determinowana zasobami ludzkimi - badaczami zaangażowanymi w działalność $\mathrm{B}+\mathrm{R}$, finansami przeznaczonymi dla personelu $\mathrm{B}+\mathrm{R}$ oraz zamożnością danego regionu,

- dane źródłowe pochodzą z opracowań Eurostatu i Europejskiego Urzędu Patentowego (EPO), oszacowań Organizacji Współpracy Gospodarczej i Rozwoju (OECD), Światowej Organizacji Własności Intelektualnej (WIPO) i narodowych biur statystycznych.

W toku badań okazało się, że teoretycznie dysponowano próbą 14 okresów x 270 regionów $=3780$ obserwacji na każdej ze zmiennych przy kompletnych danych zbilansowanych. W rzeczywistości otrzymano szereg 3063 obserwacji dla danych niezbilansowanych 266 regionów. W przypadku czterech regionów występowały duże braki w danych. Badania na danych niezbilansowanych są możliwe i często stosowane (Wójcik-Mazur, Szajt, 2015), jednak wnioskowanie na ich podstawie nie zawsze jest uzasadnione - zwłaszcza gdy obiekt, dla którego wnioskujemy, charakteryzuje się krótszym lub dłuższym od większości obiektów szeregiem czasowym. Po zbilansowaniu otrzymano próbę dla 245 regionów i dla lat 2007-2012, co dało 1470 obserwacji.

W badaniu przyjęto, że właściwym modelem będzie model potęgowy (Szajt, 2009). Ponadto, aby otrzymać relacje długo- i krótkookresowe oraz wskazać zbieżności względem hipotetycznego punktu równowagi, zastosowano konstrukcję korekty błędem. Proponowany model przyjął zatem postać:

$$
\begin{gathered}
\Delta \log P A T_{i t}=\alpha_{i 1}^{*}+\left(\alpha_{1}-1\right)\left(\log P A T_{i t-1}-\delta_{1} \log G E R D_{i t-1}-\delta_{2} \log R E C H_{i t-1}-\delta_{3} \log G D P_{i t-1}\right)+ \\
+\beta_{1} \Delta \log G E R D_{i t}+\beta_{2} \Delta \log R E C H_{i t}+\beta_{3} \Delta \log G D P_{i t}+\varepsilon_{i t}
\end{gathered}
$$

gdzie:

$P A T_{i t}$ - liczba patentów zgłoszonych przez rezydentów w przeliczeniu na 1000 osób aktywnych zawodowo $\mathrm{w}$ danym okresie $t$ dla $i$-tego regionu,

$G E R D_{i t}$ - wydatki brutto na działalność B+R (według parytetu siły nabywczej w cenach stałych z 2010 roku) w przeliczeniu na 1000 osób personelu zatrudnionego w B+R dla $i$-tego regionu w okresie $t$,

$\mathrm{RECH}_{i t}$ - liczba badaczy w sektorze $\mathrm{B}+\mathrm{R}$ w przeliczeniu na 1000 osób aktywnych zawodowo w danym okresie $t$ dla $i$-tego regionu,

$G D P_{i t}$ - produkt krajowy brutto (według parytetu siły nabywczej w cenach stałych z 2010 roku) w przeliczeniu na 1000 mieszkańców dla $i$-tego regionu w okresie $t$,

$\alpha^{*}$ - zdekomponowany wyraz wolny.

Estymacji dokonano z wykorzystaniem pakietu GRETL. 


\section{REZULTATY ESTYMACJI MODELU AKTYWNOŚCI PATENTOWEJ}

$\mathrm{W}$ toku estymacji otrzymano model z dekompozycją wyrazu wolnego dla regionów.

Tab. 3. Wartości ocen parametrów równania modelu aktywności patentowej dla regionów

\begin{tabular}{|l|c|c|c|}
\hline \multicolumn{1}{|c|}{ Zmienna } & Parametr & Ocena & \multicolumn{1}{c|}{$\mathrm{p}$} \\
\hline$P A T_{\mathrm{t}-1}$ & $\alpha_{1}$ & 0,418 & $<0,0001$ \\
\hline$G E R D_{\mathrm{t}-1}$ & $\delta_{1}$ & 0,592 & 0,0003 \\
\hline$R E C H_{\mathrm{t}-1}$ & $\delta_{2}$ & $-1,586$ & $<0,0001$ \\
\hline$G D P_{\mathrm{t}-1}$ & $\delta_{3}$ & $-4,080$ & $<0,0001$ \\
\hline$\triangle G E R D_{\mathrm{t}}$ & $\beta_{1}$ & 0,271 & 0,0031 \\
\hline$\triangle R E C H_{t}$ & $\beta_{2}$ & $-0,399$ & $<0,0001$ \\
\hline$\triangle G D P_{t}$ & $\beta_{3}$ & $-1,634$ & $<0,0001$ \\
\hline
\end{tabular}

Źródło: opracowanie własne

Otrzymany model charakteryzował się dopasowaniem mierzonym $\mathrm{R}^{2}$ na poziomie 0,381, co było wartością istotną statystycznie $\left(\mathrm{F}_{(218,1006)}=2,836\right.$; $\left.\mathrm{p}<0,001\right)$. Poziom inercji systemu nie był wysoki $\left(\alpha_{1}=0,418\right)$. Nakłady na działalność $\mathrm{B}+\mathrm{R}$, zarówno w długim, jak i w krótkim okresie, miały dodatnią elastyczność. Pozostałe determinanty wskazywały na relację ujemną. Pamiętać jednak należy, że interpretację przeprowadzono z założeniem ceteris paribus. Zatem wzrost liczby badaczy powoduje spadek aktywności patentowej, ze względu na automatyczne zmniejszenie się środków (stałych) poprzez większą liczbę jednostek, dla których trzeba je poznaczyć. Z punktu widzenia przeprowadzanych analiz kluczowa jest jednak istotność zdekomponowanych wyrazów wolnych dla 211 regionów. Pozostałym - które możemy uznać za typowe z perspektywy charakterystyki modelu - przyporządkowujemy jedynie wspólny wyraz wolny. W przypadku 21 państw mamy więcej niż jeden wyraz wolny (co wynika z podziału regionalnego). Na ryc. 5. przedstawiono wartości maksymalne, średnie i minimalne zdekomponowanych wyrazów wolnych dla tych właśnie państw.

Otrzymane wyniki wskazują wyraźnie na bardzo duże zróżnicowanie pomiędzy poszczególnymi regionami Unii Europejskiej w odniesieniu do potencjału innowacyjnego. Właśnie otrzymane zdekomponowane wyrazy wolne traktować można jako swojego rodzaju miary tego potencjału. Pamiętać należy, że w modelu potęgowym wyraz wolny oddziałuje na wartość końcową w sposób multiplikatywny. Na ryc. 5. przedstawiono wartości przed odlogarytmowaniem. Stąd odczytywać je możemy jako osłabiające (z minusem) lub wzmacniające aktywność patentową. W praktyce najwyższy poziom $\alpha_{233}=95,4211$ otrzymujemy dla regionu Inner London, a najmniejszy dla rumuńskiego Regionu Południowo-Wschodniego (Sud-Est) $\alpha_{193}=0,0017$.

Z drugiej strony, jeżeli porównamy wartości średnie dla wszystkich państw i wartości indywidualne w obszarze poszczególnych państw, okazuje się, że proporcja pomiędzy najwyższą i najniższą średnią dla państwa w Unii to jak 101 : 1, a dla najbardziej 
Ryc. 5. Zróżnicowanie zdekomponowanych wyrazów wolnych

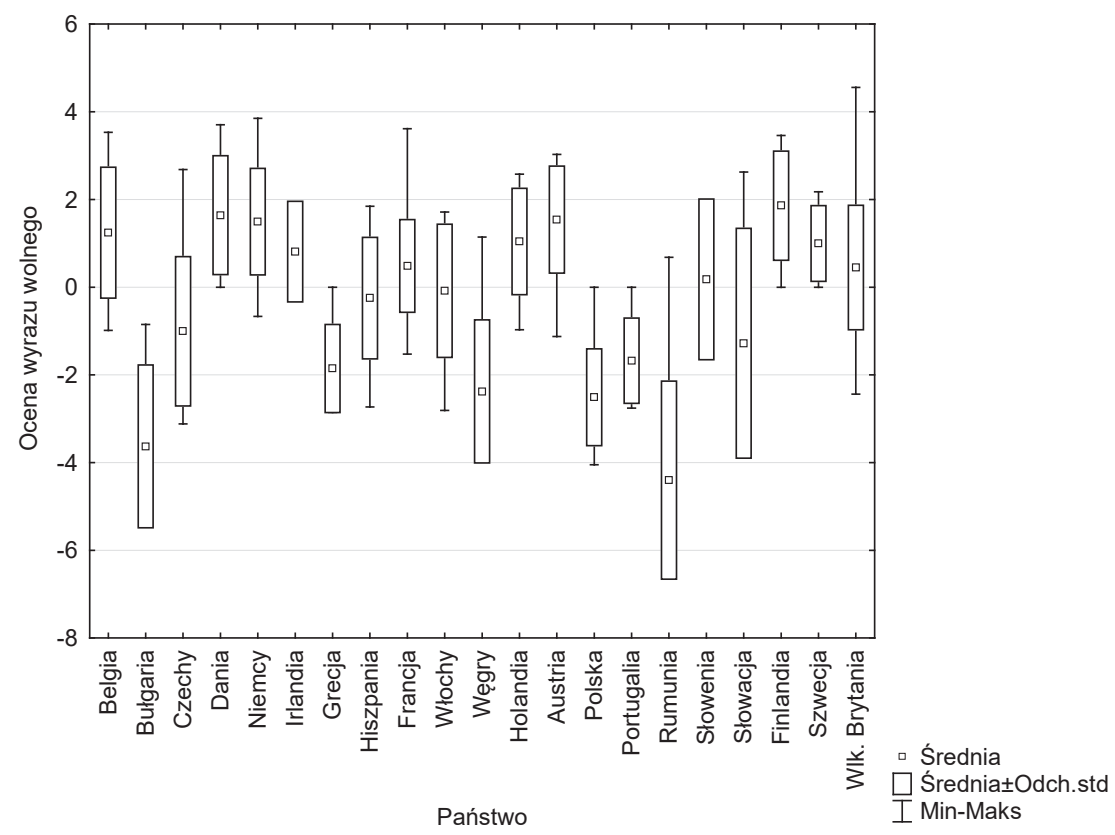

Źródło: opracowanie własne z wykorzystaniem pakietu Statisca 10

zróżnicowanej Wielkiej Brytanii to aż 1092 : 1. Różnica jest ogromna i świadczy o daleko idących różnicach w efektywności poszczególnych regionów przy podobnych nakładach. Otrzymane wyniki wskazują wyraźnie na potrzebę analizy danych na poziomie regionalnym, co pozwala na otrzymanie bardziej precyzyjnych wyników.

\section{PoDSUMOWANIE}

Aktywność patentowa na poziomie regionu jest miernikiem tejże aktywności ze strony podmiotów zlokalizowanych w tym obszarze. Ze względu na swoje uwarunkowania ekonomiczne, ale także geograficzne, historyczne, demograficzne czy kulturowe, aktywność ta nie jest jednorodna. Mimo usilnych dążeń organów unijnych do pewnej konwergencji w tym aspekcie obserwujemy sytuację daleką od oczekiwań. Poziom tej aktywności, będącej pewnym wyznacznikiem innowacyjności, jest bardzo silnie zróżnicowany. Mimo bezsprzecznych wspólnych cech, determinujących wzrost lub spadek tejże aktywności, jej poziom w największym stopniu determinowany jest uwarunkowaniami o charakterze indywidualnym, generującymi istnienie swojego rodzaju potencjału innowacyjnego. Rozpoznanie tych uwarunkowań jest trudne ze względu na ich często jakościowy charakter, natomiast identyfikacja poziomu tego potencjału została potwierdzona w toku przedstawionych w artykule badań. 
Prezentowane wyniki wskazują na istotne różnice w poziomie aktywności patentowej i potencjału innowacyjnego na poziomie regionów należących do tego samego państwa. Być może - i to powinno być kolejnym etapem prac - każde z państw charakteryzuje się pewnym naturalnym podziałem aktywności poszczególnych regionów w odniesieniu do różnych dziedzin gospodarki. To z tego faktu wynikać może silne zróżnicowanie badanej aktywności patentowej. Być może identyfikacja pewnych poziomów progowych umożliwi w przyszłości wyznaczanie realnych do osiągnięcia celów w aspekcie konwergencji poziomu aktywności innowacyjnej regionów w Unii Europejskiej.

\section{Literatura}

\section{References}

Acsa, Z.J., Anselin, L., Varga, A. (2002). Patents and innovation counts as measures of regional production of new knowledge. Research Policy, 31, 1069-1085. DOI: 10.1016/S00487333(01)00184-6

Brezdeń, P., Spallek, W. (2013). Przestrzenne zróżnicowanie poziomu innowacyjności regionalnej gospodarki województwa dolnośląskiego. Prace Komisji Geografii Przemysłu Polskiego Towarzystwa Geograficznego, 23, 9-25.

Corredoira, R.A., Banerjee, P.M. (2015). Measuring patent's influence on technological evolution: A study of knowledge spanning and subsequent inventive activity. Research Policy, 44, 508521. DOI: 10.1016/j.respol.2014.10.003

Eurostat (2015, 10 września). Pozyskano z http://ec.europa.eu/eurostat/data/database

Firlej, K.A. (2013). Innowacyjność jako instrument podnoszenia konkurencyjności regionów. Roczniki Ekonomiczne Kujawsko-Pomorskiej Szkoły Wyższej w Bydgoszczy, 6, 211-221.

Janasz, W. (1999). Innowacyjne strategie rozwoju przemysłu. Szczecin: Fundacja Uniwersytetu Szczecińskiego.

Kozioł-Nadolna, K. (2015). Nowy wymiar innowacji we współczesnej gospodarce. W: J. Wiśniewska, $\mathrm{K}$. Janasz (red.). Innowacje i procesy transferu technologii w strategicznym zarzadzaniu organizacjami. Warszawa: Difin, 62-80.

Krawczyk-Sokołowska, I. (2012). Innowacyjność przedsiębiorstw i jej regionalne uwarunkowania. Częstochowa: Wydawnictwo Politechniki Częstochowskiej.

Markowska, M. (2012). Dynamiczna taksonomia innowacyjności regionów. Wrocław: Wydawnictwo Uniwersytetu Ekonomicznego we Wrocławiu.

Proniewski, M. (2013). Innowacyjność a rozwój regionalny Unii Europejskiej. Ekonomia i Prawo, 12(3), 441-462.

Quatraro, F. (2009). Diffusion of Regional Innovation Capabilities: Evidence from Italian Patent Data. Regional Studies, 43(10), 1333-1348. DOI: 10.1080/00343400802195162

Strahl, D. (red.). (2012). Innowacyjność europejskiej przestrzeni regionalnej a dynamika rozwoju gospodarczego. Wrocław: Wydawnictwo Uniwersytetu Ekonomicznego we Wrocławiu.

Szajt, M. (2009) Estimation of Disproportions in Patent Activity of OECD Countries Using SpatioTemporal Methods. Dynamic Econometric Models, 9, 91-98.

Szajt, M. (2010). Działalność badawczo-rozwojowa w kształtowaniu aktywności innowacyjnej w Unii Europejskiej. Częstochowa: Wydawnictwo Politechniki Częstochowskiej.

Tavassoli, S., Carbonara, N. (2014). The role of knowledge variety and intensity for regional Innovation. Small Business Economics, 43, 493-509. DOI: 10.1007/s11187-014-9547-7

Wanzenböck, I., Scherngell, T., Brenner, T. (2014). Embeddedness of regions in European knowledge networks: a comparative analysis of inter-regional R\&D collaborations, co-patents and 
co-publications. The Annals of Regional Science, 53, 337-368. DOI: 10.1007/s00168-0130588-7

Wójcik-Mazur, A., Szajt, M. (2015). Determinants of Liquidity Risk in Commercial Banks in the European Union. Argumenta Oeconomica, 2(35), 25-48. DOI: 10.15611/aoe.2015.2.02

Yanhui, W., Huiying, Z., Jing, W. (2015). Patent elasticity, R\&D intensity and regional innovation capacity in China. World Patent Information, 43, 50-59. DOI: 10.1016/j.wpi.2015.10.003

Yoon, H., Yun, S., Lee, J., Phillips, F. (2015). Entrepreneurship in East Asian Regional Innovation Systems: Role of social capital. Technological Forecasting \& Social Change, 100, 83-95. DOI: 10.1016/j.techfore.2015.06.028

Zioło, Z. (2012). Miejsce innowacyjności w kształtowaniu procesów rozwoju gospodarczego układów przestrzennych. Prace Komisji Geografii Przemysłu Polskiego Towarzystwa Geograficznego, 20, 9-32.

Marek Szajt, dr hab. prof. Politechniki Częstochowskiej, Politechnika Częstochowska, Wydział Zarządzania, Katedra Ekonometrii i Statystyki. Jest profesorem Politechniki Częstochowskiej i kierownikiem Katedry Ekonometrii i Statystyki na Wydziale Zarządzania. Jego zainteresowania naukowo-badawcze dotyczą w szczególności: badania innowacyjności na poziomie mikro-, mezo- i makro-, badań przestrzennych, analiz symulacyjnych, modelowania ekonometrycznego z wykorzystaniem prób przestrzenno-czasowych. Autor i współautor ponad 100 publikacji naukowych oraz raportów wykonywanych na zlecenie instytucji samorządowych i przedsiębiorstw.

Marek Szajt, Ph.D. is an associate professor at the Częstochowa University of Technology and the head of Department of Econometrics and Statistics of Faculty of Management. His research interests include, in particular the study of innovation in the micro-, meso- and macro-scale; spatial research; simulation analysis; econometric modelling using spatio-temporal sample. He is the author and co-author of over 100 publications and reports carried out on behalf of local government institutions and enterprises.

\section{Adres/address:}

Politechnika Częstochowska

Wydział Zarządzania

Katedra Ekonometrii i Statystyki

al. Dąbrowskiego 69, 42-201 Częstochowa, Polska

e-mail: marszajt@zim.pcz.pl 